\title{
Pengaruh Faktor Internal terhadap Kemampuan Guru Mengajar Agama Hindu
}

\author{
I Gusti Agung Made Gede Mudana \\ Jurusan Dharma Acarya, STAHN Kuturan Singaraja \\ e-mail: agungmudana1961@gmail.com
}

\begin{abstract}
Abstrak
Tujuan pokok dari penelitian ini adalah ingin mengetahui hubungan antara disiplin kerja guru, motivasi kerja guru dan semangat kerja guru dengan kemampuan mengajar guru agama hindu di sekolah dasar. Penelitian ini dilakukan di Denpasar dengan mengobesrvasi 80 guru sebagai responden disekolah adasr pada tiga kecamatan yang ada di Kota Denpasar. Data dianalisis menggunakan statistic inferensial dengan mengunakan angket dan observasi. Berdasarkan hasil penelitian menunjukkan bahwa: Pertama, penelitian ini menemukan bahwa hubungan antara disiplin kerja guru (X1) dengan kemampuan guru mengajar agama Hindu ( $Y$ yang dinyatakan dalam bentuk persamaan regresi $\hat{Y}=6,523+0,0467$ X1 dengan ry $1=0,404$ adalah signifikan. Kedua, hubungan antara motivasi kerja guru (X2) dengan kemampuan guru mengajar agama Hindu $(Y)$ yang dinyatakan dalam bentuk persamaan regresi $\hat{Y}=8,721+$ 0,0445 , koefisien ry2 $=0,402$ adalah signifikan. Ketiga, hubungan antara semangat kerja guru (X3) dengan kemampuan guru mengajar agama Hindu $(\mathrm{Y})$ yang dinyatakan dalam bentuk persamaan regresi $\hat{Y}=10,046+0,0529$ X3 ry $3=0,272$ adalah signifikan. Keempat, hubungan antara disiplin kerja guru, motivasi kerja guru dan semangat kerja guru secara bersama-sama dengan kemampuan guru mengajar agama Hindu yang dinyatakan dalam bentuk persamaan regresi $\hat{Y}=0,762+0,0472 \times 1+0,0348 \times 2+0,0553 \times 3$ dan koefisien korelasi ganda $R$ y. $123=$ 0,607 adalah signifikan. Kelima Penelitian ini juga menemukan bahwa berdasarkan koefisien korelasi parsial ternyata (1) hubungan antara disiplin kerja guru dengan kemampuan guru mengajar menempati peringkat pertama jika motivasi kerja guru dan semangat kerja guru dikontrol, (2) hubungan antara motivasi kerja guru dengan kemampuan guru mengajar menempati peringkat kedua jika disiplin kerja guru dan semangat kerja guru dikontrol, dan (3) hubungan antara semangat kerja guru dengan kemampuan guru mengajar menempati peringkat ketiga jika disiplin kerja guru dan motivasi kerja guru dikontrol.
\end{abstract}

Kata Kunci: Kemampuan Guru Mengajar Agama Hindu

\begin{abstract}
The main objective of this study is to find out the relationship between teacher work discipline, teacher work motivation and teacher morale with the ability to teach Hindu religion teachers in elementary school. This research was conducted in Denpasar by inspiring 80 teachers as respondents in schools in three sub-districts in Denpasar City. Data were analyzed using inferential statistics using questionnaires and observations. Based on the results of the study show that: First, this study found that the relationship between teacher work discipline (X1) with the teacher's ability to teach Hinduism ( $Y$ expressed in the form of a regression equation $\hat{Y}=6.523+0.0467 X 1$ with $r y 1=0.404$ is significant. Second, the relationship between teacher work motivation (X2) with the teacher's ability to teach Hinduism $(Y)$ expressed in the form of a regression equation $\hat{Y}=8.721+0.0445$, the coefficient of ry $2=0.402$ is significant. Third, the relationship between teacher work morale $(X 3)$ and the teacher's ability to teach Hinduism $(Y)$ expressed in the form of a regression equation $\hat{Y}=10,046+0,0529$ X3 ry3 $=0,272$ is significant Fourth, the relationship between teacher work discipline, teacher work motivation and teacher work spirit together with teacher's ability teaching Hinduism which is expressed in the form of a regression equation $\hat{Y}=0.762+0.0472 X 1+0.0348 X 2+0.0553 X 3$ and multiple correlation coefficients $R$ y.123 $=0.607$ is significant. This study also found that based on the partial correlation coefficient it turns out (1) the relationship between teacher work discipline and teacher teaching ability is ranked first if teacher work motivation and teacher work morale are controlled, (2) the relationship between teacher work motivation and teacher teaching ability is ranked second, if the teacher's work discipline and teacher's work spirit are controlled, and (3) the relationship between teacher work morale and teaching teacher's ability is ranked third if the teacher's work discipline and teacher's work motivation are controlled.
\end{abstract}

Keywords: Teacher's Ability To Teach Hindu Religion 


\section{Pendahuluan}

Guru sebagai salah satu faktor penentu dalam pencapaian tujuan pendidikan serta meningkatkan mutu pendidikan di sekolah. Guru juga bertindak sebagai fasilitator yang menyebabkan terciptanya kondisi kondusif bagi peserta didik dan disamping juga mempunyai tugas utama sebagai pengajar. Artinya guru dapat melaksanakan tugas mengajar sebagaimana yang diharapkan, akan berpengaruh pada peningkatan hasil belajar siswa. Namun kenyataannya masih ada sebagian masyarakat meragukan kemampuan guru mengajar. Keraguan terhadap kemampuan guru mengajar tersebut dipandang wajar karena hal itu merupakan suatu bentuk kontrol untuk mengoreksi secara terus menerus, sehingga lama kelamaan tugas guru mengajar dapat dilaksanakan dengan lebih baik. Mutu pendidikan tidak akan terwujud walaupun didukung oleh kurikulum yang sempurna, buku-buku pelajaran yang lengkap dan sarana prasarana yang tersedia bilamana guru-guru dalam melaksanakan pembelajaran tersebut kurang berkualitas.

Untuk dapat melaksanakan proses belajar mengajar yang baik dan menghasilkan lulusan yang berkualitas, diperlukan kemampuan guru mengajar. Kemampuan guru mengajar yang dimaksud adalah kemampuan profesional, yaitu kemampuan yang sesuai dengan urutan kegiatan yang meliputi : kemampuan merencanakan pembelajaran, mengelola kegiatan belajar mengajar dan menilai kegiatan belajar mengajar. Guru agama Hindu dikatakan telah melaksanakan tugasnya dengan baik apabila ia mampu secara nasional melaksanakan:(1)lebih menitik beratkan pencapaian target kompetensi (attainment targets)dari pada penguasaan materi;(2)lebih mengakomodasikan keragaman kebutuhan dan sumber daya pendidikan yang tersedia;(3)memberikan kebebasan yang lebih luas kepada pelaksana pendidikan dilapangan yang mengembangkan dan yang melaksanakan program pembelajaran sesuai dengan kebutuhan. (kurikulum pendidikan agama Hindu berbasis kompetensi sekolah dasar,2003:1)

Kemampuan guru mengajar dalam penelitian ini adalah kemampuan guru mengajar bidang studi Agama Hindu. Dalam perjalanan kehidupan dan peradaban manusia di awal milenium ketiga ini telah terjadi perubahan,manusia terpacu untuk mengembangkan pendidikan dalam ilmu-ilmu social,ilmu alam,ilmu pasti,maupun ilmu terapan, masyarakat telah sampai pada era moderen tertinggi,sangat maju dalam atribut kehidupan duniawi.

Dengan munculnya sejumlah krisis kehidupan berbangsa dan bernegara yang meliputi politik,ekonomi,social,hokum,etnis agama,golongan dan ras perilaku menyimpang ,belakangan ini dipertanyakan peranan dan efektifitas pendidikan agama di sekolah sebagai pemberi nilai acuan tertinggi secara sepiritual terhadap kesejahtraan nasional.Dengan asumsi ini jika pendidikan agama dilakukan dengan baik ,maka kerjasama dan toleransi dalam masyarakat pun akan lebih baik.

Namun kenyataan seolah-olah pendidikan agama tidak banyak memberikan kontribusi terhadap pembekalan peserta didik hingga periode reformasi ini ternyata setelah ditelusuri pendidikan agama menghadapi persoalan dari berbagai sisi ,antara lain : (1) waktu yang disediakan hanya dua jam pelajaran dengan muatan materi yang begitu padat; (2) materi pendidikan agama Hindu termasuk bahan ajar susila lebih berfokus pada pengayaan pengetahuan (kognetif)dan minim dalam pembentukan sikap (afektif)serta pembiasaan (Psikomotorik)sehingga peranan humanitis dari susila tidak banyak terialisasi;(3)kurangnya keikut sertaan guru mata pelajaran lain dalam memberi motivasi peserta didik untuk memperaktekkan nilai-nilai pendidikan agama dalam kehidupan sehari-hari;(4)lemahnya sumberdaya pendidikan seperti kurangnya kemampuan guru dalam pengembangan pendekatan dan metode yang lebih variatif,minimnya berbagai sarana pelatihan dan pengembangan,rendahnya sambutan orang tua siswa yang kurang mendukung pendidikan agama peserta didik.(Santika,2003:2-3).

Secara umum tujuan pendidikan agama Hindu adalah untuk menumbuh kembangkan dan meningkatkan Sradha (Iman)dan bhakti(Ketaqwaan)dari peserta didik kehadapan Brahman melalui pemberian ,pemupukan ,penghayatan dan pengamalan ajaran agama ,sehingga menjadi insan Hindu yang darmika dan mampu mewujudkan cita-cita luhur Moksartam Jagadhita.

Wijaya (1991) mengemukakan secara fungsional persepsi guru dibebani dengan tiga tugas utama, yaitu : mendidik, mengajar dan melatih peserta didik. Untuk menyeimbangkan tugas-tugas tersebut salah satu caranya adalah menegakkan disiplin kerja, baik jam kerja maupun perbuatan atau tingkah laku. Senada dengan pendapat tersebut, Amidjaya (1979) menyatakan bahwa kualitas guru yang dibutuhkan dalam era pembangunan adalah mereka yang mampu dan siap berperan secara profesional dalam dua lingkungan besar yaitu sekolah 
dan masyarakat. Pendapat ini memberi arti bahwa guru yang profesional adalah guru yang mampu menunjukkan disiplin kerja yang tinggi dalam tugasnya dan dapat berinteraksi dengan masyarakat sekolah dan peserta didik, sesama guru serta anggota masyarakat di luar sekolah. Para pendidik yang memiliki disiplin kerja tinggi tampak lebih siap dalam segi materi palajaran, strategi belajar, dalam menciptakan suasana dan nuansa mendidik yang dipenuhi semangat dan motivasi, juga dalam hal kemampuan mengajarnya. Hasil penelitian Indrakusuma (1985) menjelaskan adanya hubungan antara faktor-faktor motivasi dengan keefektivan kerja, yang kemudian dilanjutkan oleh Telelepta (1988) dengan hasil penelitiannya bahwa terdapat hubungan yang signifikan antara masalah-masalah personil dengan semangat kerja. Kedua hasil penelitian tersebut didukung oleh Sulaiman (1992) dalam penelitiannya yang menyimpulkan adanya hubungan prilaku kepemimpinan dengan semangat kerja. Begitu juga hasil penelitian (Paramartha, 2003) menyebutkan dalam tesisnya ada pengaruh yang signipikan terhadap disiplin kerja, motivasi kerja dan semangat kerja terhadap kemampuan guru mengajar sejarah di SMA se Kota Denpasar.

Menurut Gagne (1987) disiplin adalah rasa tanggung jawab untuk bertingkah laku dan mengikuti tata tertib yang baik sesuai dengan aturan norma yang berlaku. Dengan demikian ciri utama dari disiplin adalah adanya keteraturan dan ketertiban.

Halim dalam Anggraini Naskawati (2000: 4) mengemukakan disiplin kerja yang terlaksana secara konsisten merupakan iklim yang memungkinkan berlangsungnya proses belajar yang efektif dan efisien. Disiplin penting bagi guru-guru karena guru mempunyai peranan yang menentukan dalam membina mentalitas peserta didik. Oleh karena itu menerapkan disiplin secara konsisten harus dimulai dari disiplin para guru di sekolah. Begitu pula didalam pengelolaan kelas, disiplin merupakan suatu masalah penting, karena tanpa adanya kesadaran akan keharusan melaksanakan aturan yang sudah ditentukan sebelumnya, pengajaran tidak mungkin mencapai target yang maksimal.

Di samping disiplin kerja, motivasi kerja juga mempengaruhi kemampuan mengajar guru. Motivasi kerja (work motivation) adalah sikap atau perasaan-perasaan yang timbul pada diri seseorang terhadap pekerjaannya dalam rangka memenuhi kebutuhannya yang dapat menyebabkan naik dan turunnya semangat dan kegairahan kerja. Adapun motivasi kerja meliputi : prestasi, pengakuan, pekerjaan, tanggung jawab, kesempatan untuk maju, sikap atau perasaan-perasaan terhadap pekerjaan. Motivasi kerja dapat menjadi positif apabila : (1) merasa senang, (2) cinta, (3) tertarik pada pekerjaan. Dan bisa juga motivasi kerja menjadi negatif antara lain : (1) benci, (2) bosan, (3) tertekan (Indrakusumah, 1985). Menurut Stoner (1982) orang-orang yang berhasil dalam pekerjaannya adalah orang yang rata-rata mempunyai motivasi tinggi.

Berdasarkan uraian di atas, ada keselarasan antara motivasi dengan semangat kerja. Tetelepta (1988) menjelaskan bahwa semangat kerja berasal dari kepuasan yang diperoleh pekerja (guru) didalam kerja dan dalam hubungan mereka dengan teman sekerja.Hasil penelitian tersebut didukung oleh Sulaeman(1992)dalam penelitiannya yang menyimpulkan adanya hubungan prilaku kepemimpinan dengan semangat kerja. Sedangkan Hoy \& Miskel (1997) mengemukakan bahwa semangat kerja merupakan keyakinan, antusianisme, kepercayaan dan perasaan akan kemampuan berprestasi yang mendasari perilaku guru. Selanjutnya Hoy \& Miskel (1987) mengemukakan bahwa guru yang lebih terpuaskan, melakukan pekerjaan lebih baik ketimbang guru yang tidak terpuaskan. Dari hasil penelitian Strickland (dalam Gorton, 1976) menjelaskan ada sepuluh faktor yang dapat meningkatkan dan dapat menurunkan semangat kerja guru. Faktor-faktor yang dapat meningkatkan semangat kerja guru adalah : (1) rekan kerja yang kooperatif dan suka membantu dalam membagikan gagasan dan materi, (2) kepala sekolah yang kooperatif dan senang menolong, (3) orang tua murid yang kooperatif dan apresiatif, (4)perlengkapan dan fasilitas yang memadai, (5) kebebasan mengajar, (6) murid yang sopan, (7) bangunan sekolah yang memadai, (8) minat murid dalam pekerjaan sekolah, (9) suvervisor yang suka menolong dan, (10) sekolah yang terorganisasi dan kebijakan yang terformulasikan dengan baik. Sedangkan faktor-faktor yang dapat menurunkan semangat kerja adalah : (1) kurang bebas berkomunikasi dengan murid sepanjang hari di sekolah, (2) tugas-tugas ketatausahaan, (3) kurang kerja sama dan dorongan dari Kepala Sekolah, (4) bangunan sekolah yang tidak memadai, (5) kurang kerja sama dengan guru-guru, (6) beban mengajar yang berlebihan, (7) gaji yang rendah, (8) minat murid dalam pekerjaan kurang, (9) disiplin murid yang rendah, (10) kurang perlengkapan dan fasilitas yang memadai.

Tetapi kenyataan yang terjadi di lapangan masih terjadi kesenjangan bahwa disiplin kerja, motivasi kerja, dan semangat kerja sebagai suatu hal yang sangat berpengaruh dalam 
kemampuan mengajar guru dirasakan belum optimal. Untuk itu perlu dilakukan penelitian dengan judul "Pengaruh Faktor-faktor Internal terhadap kemampuan guru mengajar Agama Hindu pada Sekolah Dasar di Kota Denpasar". Adapun rumusan masalah penelitian ini adalah sebagai berikut: 1) Apakah terdapat hubungan antara disiplin kerja guru dengan kemampuan guru mengajar Agama Hindu pada Sekolah Dasar di Kota Denpasar?, 2) Apakah terdapat hubungan antara motivasi kerja guru dengan kemampuan guru mengajar Agama Hindu pada Sekolah Dasar di Kota Denpasar?, 3) Apakah terdapat hubungan antara semangat kerja guru dengan kemampuan guru mengajar Agama Hindu pada Sekolah Dasar di Kota Denpasar? , 4) Bagaimana tingkat disiplin kerja guru,motivasi kerja guru,semangat kerja guru agama Hindu pada Sekolah Dasar di Kota Denpasar?, 5) Apakah secara bersama-sama terdapat hubungan antara disiplin kerja guru, motivasi kerja guru, dan semangat kerja guru dengan kemampuan mengajar guru Agama Hindu pada Sekolah Dasar di Kota Denpasar?

\section{Metode}

Subyek penelitian ini adalah seluruh guru Agama Hindu di Sekolah Dasar berstatus PNS baik mengajar di Sekolah Dasar Negeri, maupun mengajar di Sekolah Dasar Swasta di seluruh desa pada tiga Kecamatan se kota Denpasar sejumlah 104 orang yang terdiri dari 46 laki-laki dan 58 perempuan .

Sampel dalam penelitian ini adalah proporsional area random sampling, maksudnya adalah kota Denpasar terdiri dari tiga kecamatan,masing-masing kecamatan terdiri dari beberapa kelurahan, masing-masing kelurahan terdiri dari beberapa desa. Guru agama Hindu di Sekolah-sekolah yang ada di desa inilah akan dijadikan sebagai populasinya. keseluruhan populasi tersebut berjumlah 104 orang. Untuk menentukan jumlah sample mempergunakan tabel Krejcie Morgan taraf kepercayaan $95 \%$ didapatkan jumlah sample 80 orang. Dari jumlah sample supaya mewakili populasi dipergunakan proses menurut prosedur dengan cara acak/random yaitu diberi kesempatan yang sama untuk dipilih bagi setiap individu atau unit dalam keseluruhan populasi. Prosedur random dipergunakan sistem undian.. Hal ini dapat dilihat dalam Tabel 1 sebagai berikut :

Tabel 1. Rincian Sampel Penelitian

\begin{tabular}{llllll}
\hline \multirow{2}{*}{ No. } & \multirow{2}{*}{ Kecamatan } & Jumlah Guru Agama Hindu & Jumlah & Jumlah \\
& & $\mathrm{L}$ & $\mathrm{P}$ & Populasi & Sampel \\
\hline 1 & Denpasar Timur & 18 & 19 & 37 & 28 \\
2 & Denpasar Selatan & 14 & 5 & 19 & 15 \\
3 & Denpasar Barat & 14 & 34 & 48 & 37 \\
& Jumlah $\mathbf{1 + 2 + 3 =}$ & $\mathbf{4 6}$ & $\mathbf{5 8}$ & $\mathbf{1 0 4}$ & $\mathbf{8 0}$ \\
\hline
\end{tabular}

Langkah-langkah yang ditempuh dan metode pengumpulan data yang digunakan dalam penelitian ini adalah data tentang kemampuan guru mengajar, disiplin kerja guru, motivasi kerja guru, dan semangat kerja guru diperoleh dengan menggunakan angket, yang telah di uji validitasnya secara riil. Sebagai responden adalah guru agama Hindu yang ada pada Sekolah Dasar di Kota Denpasar. Angket/kuesioner disiplin kerja guru, motivasi kerja guru dan semangat kerja guru diisi oleh guru yang mengajar agama Hindu, sedangkan angket/kuesioner kemampuan guru mengajar agama Hindu di kelas 3 dilakukan oleh peneliti dengan menggunakan metode observasi langsung di dalam kelas dimana guru itu sedang mengajar.

\section{Hasil dan Pembhasan}

Penelitian ini tergolong penelitian ex post facto dengan rancangan deskriptif korelasional. Penelitian ex post facto, karena dalam penelitian ini tidak diadakan perlakukan (treatment) atau manipulasi ubahan-ubahan penelitian. penelitian hanya mengungkap data berdasarkan hasil pengukuran gejala yang telah ada secara wajar pada diri responden. Dalam kaitan ini Arikunto (1998) mengungkapkan "correlational research attems to investigate possible relationships among variables without trying to influence those variable" Yang dicari hubungannya adalah hubungan antara variabel bebas (independent variable) meliputi : disiplin kerja (X1), variabel motivasi kerja (X2), variabel semangat kerja (X3), dengan variabel terikat (dependent variable) yaitu kemampuan guru mengajar $(\mathrm{Y})$. Dengan demikian kontelasi antara variabel bebas dan variabel terikatnya dapat digambarkan sebagai berikut : 


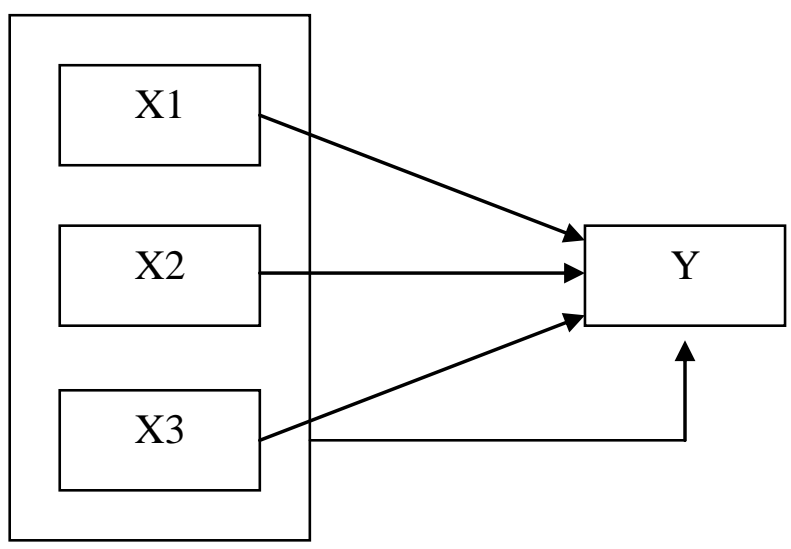

Gambar 1. Rancangan Penelitian

\author{
Keterangan : \\ $Y=$ Kemampuan kerja guru \\ $\mathrm{X} 1=$ Disiplin kerja guru \\ $\mathrm{X} 2$ = Motivasi kerja guru \\ X3 = Semangat kerja guru
}

Populasi penelitian ini adalah seluruh guru Agama Hindu di Sekolah Dasar berstatus PNS baik mengajar di Sekolah Dasar Negeri, maupun mengajar di Sekolah Dasar Swasta di seluruh desa pada tiga Kecamatan se-kota Denpasar sejumlah 104 orang.

\title{
Kemampuan Guru Mengajar
}

Kemampuan guru mengajar agama Hindu memiliki skor riil terkecil 10 dan skor terbesar 15 dari skor terendah yang mungkin dicapai (skor minimal ideal) 7 dan skor tertinggi yang mungkin tercapai (skor maksimal ideal) 35. Dari skor tersebut skor rata-rata (mean) diperoleh 12,601, maka skor rata-rata observasi yang didapat tergolong pada klasifikasi rendah, karena berada di bawah rata-rata ideal 34,999. Dengan demikian dapat dikatakan bahwa kemampuan guru mengajar agama Hindu pada SD di Kota Denpasar perlu mendapatkan pembinaan. Rendahnya kemampuan guru mengajar bisa disebabkan oleh beberapa factor yaitu ; aspek psikologi guru yang menyangkut disiplin kerja guru, motivasi kerja guru dan semangat kerja guru belum optimal dimplementasikan pada proses pengelolaan kegiatan belajar mengajar yang mungkin juga dipengaruhi oleh factor lain seperti kurang optimalnya instruktur (pengawas dan kepala sekolah) melakukan pembinaan terhadap para guru, dalam melaksanakan pembinaan tidak mengarah pada keprofesionalannya, peranan kepala sekaolah belum optimal menegakan disiplin kerja, pemberian penghargaan kepada guru tidak sesuai dengan prestasi yanag didapatkan selama bertugas.

Berdasarkan uraian tersebut, baik dari teori dan hasil penelitian dapat dijelaskan rendahnya kemampuan guru mengajar agama Hindu pada Sekolah Dasar di Kota Denpasar disebabkan oleh factor-faktor yang telah diuraikan di atas. Langkah yang harus dilakukan perlu diadakan pembinaan terhadap kemampuan guru mengajar. T Raka Joni (1984) dalam Sultoni, 1995 : 165) dalam buku Pola Pembaharuan Sistem Pendidikan di Indonesia, mengemukakan 10 kompetensi dasar yang harus dikuasai oleh guru, yaitu (a) menguasai bahan, (b) menguasai landasan pendidikan, (c) menyusun program pelajaran, (d) melaksanakan program-program pengajaran, (e) menilai proses dan hasil belajar, (f) meneyelenggarakan program bimbingan dan penyuluhan, (g) menyelenggarakan administrasi sekolah, (h) mengembangkan kepribadian, (i) berinteraksi dengan sejawat dan masyarakat, (j) menyelenggarakan penelitian sederhana untuk kepentingan mengajar.

Tinggi rendahnya kemampuan guru mengajar menurut (Darmodiharjo, 1991) pada guruguru yang professional, tinggi tingkatan komitmen dan abstraksinya, dapat menggunakan pendekatan non directive, pendekatan ini asumsi dasarnya menyatakan bahwa subjek binaan sudah punya pengetahuan dan pengalaman, maka Pembina tidak langsung mempengaruhi subjek binaan. la berangkat dengan mendengarkan pengalaman dan apa yang disajikan oleh subjek binaan. Berdasarkan pemahamannya terdapat subjek binaan mulai mengadakan pendekatan dengan menghormati pribadi subjek binaan. Pada guru-guru yang sebaliknya, drop out rendah tingkatan komitmen dan abstraksinya, dapat menggunakan pendekatan directiv, 
pendekatan ini asumsi dasarnya menyatakan perkembangan adalah hasil pengaruh factor eksternal maka psikologi yang dianut adalah psikologi behavioristik dan pendekatannya adalah direktif. Pada pendekatan direktif atau pendekatan langsung Pembina berusaha menggunakan teknik pembinaan yang lebih banyak memberi pengaruh terhadap subjek binaan. Pendekatan ini lebih banyak memberi intervensi dari pada memberi kesempatan. Sedangkan pada guru yang tinggi atau rendah diantara salah satunya, dapat menggunakan pendekatan Collaborative, asumsi dasarnya menyatakan perkembangan adalah hasil perpaduan antara factor eksternal dan internal maka psikologi yang ditugaskan adalah psikologi kognitif. Pendekatan ini berasal dari dua sisi yaitu dari atas ke bawah dan dari bawah ke atas. Pendekatan ini menciptakan situasi dan kondisi yang memungkinkan subjek binaan dapat menegembangkan kreativitasnya.

Hubungan Disiplin Kerja Guru dengan kemampuan Guru Mengajar Agama Hindu.

Dari hasil penelitian ditemukan adanaya hubungan yang positif dan signifikan antara disiplin kerja guru dengan kemampuan guru mengajar agama Hindu melalui persamaan garis regresi $\hat{Y}=6,523+0,0467 \times 1$, dengan koefisien determinan 0,164 ini berarti kontribusi sebesar $16,4 \%$. Disiplin kerja guru tergolong dalam kategori tinggi dengan rata-rata 130 dan skor maksimal ideal 150. Hasil penelitian ini memiliki arti bahwa para guru-guru yang bekerja pada Sekolah Dasar baik negeri maupun swasta di Kota Denpasar memiliki disiplin kerja yang tinggi.

Temuan ini sesuai dengan pendapat Prijodarminto (1993) yang menyatakan bahwa disiplin merupakan kondisi yang tercipta dan terbentuk melalui proses dari serangkaian yang menunjukkan nilai-nilai ketaatan, kepatuhan, kesetiaan, keteraturan dan ketertiban. Sikap dan prilaku yang demikian akan tercipta melalui proses binaan melalui keluarga, pendidikan atau pengenalan dari keteladanan lingkungannya. Disiplin yang mantap pada hakekatnya akan tumbuh dan terpencar dari hasil kesadaran manusia.

Sehubungan dengan penyelenggaraan disiplin kerja di sekolah, Suharsono (1984) mengemukan bahwa disiplin yang baik terdapat apabila guru dan staf sekolah datang ke sekolah dengan teratur dan tepat pada waktunya, berpakaian serba rapi dan baik di sekolah, menggunakan bahan-bahan atau perlengkapan dengan hati-hati, menghasilkan jumlah atau kualitas pekerjaan yang memuaskan, dalam hal ini bagi guru adalah mampu mengelola proses belajar mengajar secara efektif dan efisien sehingga pretasi belajar siswa dapat meningkat, selain itu juga mengikuti cara kerja yang ditentukan oleh organisasi sekolah serta dapat menyelesaikan pekerjaan dengan semangat yang baik (Revianto, 1987).

Hal senada Suharsono (1984) mengemukakan bahwa disiplin kerja sangat dipengaruhi oleh unsure motivasi kerja yang meliputi : (1) prestasi, yaitu seseorang yang memiliki keinginan berprestasi sebagai suatu kebutuhan dapat mendorongnya mencapai sasaran, (2) penghargaan, yaitu pengakuan atas suatu prestasi yang telah dicapai oleh seseorang akan merupakan motivasi yang kuat, (3) tantangan, yaitu adanya tantangan yang dihadapi akan merupakan motivator kuat bagi manusia untuk mengatasinya. Jika ke-3 unsur motivasi di atas diperoleh guru dalam melaksanakan tugasnya, maka akan berdampak pada kemampuan guru mengajar.

Dari uraian di atas, dapat disimpulkan bahwa untuk terselenggaranya disiplin kerja di kalangan para guru, perlu diiringi dengan peningkatan unsure-unsur motivator, disamping peningkatan kesejahteraan, sistem penilaian prestasi serta cara kepemimpinan kepala sekolah. Dengan peningkatan disiplin kerja guru ini akan berdampak pada peningkatan kemampuan guru mengajar yang lebih baik.

Hasil temuan ini membuktikan bahwa guru-guru agama Hindu Sekolah Dasar di Kota Denpasar menyadari pentingnya disiplin dalam mencapai tujuan sekolah. Ini berarti dalam melaksanakan pekerjaannya guru-guru telah memperhatikan dan mematuhi ketentuanketentuan jam kerja, peraturan tata tertib yang berlaku, perintah kedinasan atau instruksi pimpinan, dan usaha pada kerjasama, sebagaimana dikatakan Suharsono (1984) yang menjelaskan bahwa disiplin kerja itu berjalan baik apabila: (1) organisasi mematuhi dan mentaati ketentuan ketentuan waktu kerja yang berlaku, (2) mematuhi peraturan dan tata tertib, (3) mematuhi pimpinan organisasi yang dalam hal ini adalah kepala sekolah dan (4) kedisiplinan telah menjadi prilaku yang melekat pada diri anggota organisasi dalam meningkatkan kerjasama.

Dari uraian di atas, dapat diketahui bahwa apapun orientasi seseorang tentang disiplin, jelas bahwa disiplin sangat diperlukan dalam melakukan pekerjaan baik perorangan maupun kelompok demi tercapainya tujuan secara efektif dan efisien. Hasil temuan ini juga menunjukkan bahwa guru-guru telah berupaya menciptakan keadaan di lingkungan sekolah 
menjadi tertib, berdaya guna dan berhasil guna karena sekolah mempunyai tanggung jawab untuk mengajarkan tingkah laku dan tata tertib pada diri siswa (Triyanto, 1992).

Hubungan Motivasi Kerja Guru dengan Kemampuan Guru Mengajar Agama Hindu

Dari hasil penelitian ditemukan adanya hubungan positif dan signifikan antara motivasi kerja guru dengan kemampuan guru mengajar agama Hindu dengan koefisien korelasinya 0,319 dan persamaan regresinya $\hat{Y}=8,721+0,045 \mathrm{X} 2$, dengan koefisien determinannya 0,162 atau kontribusinya sebesar $16,2 \%$. Motivasi kerja guru tergolong dalam kategori tinggi, dengan rata-rata 87,160 dari skor maksimal ideal 60 . Hal ini menunjukkan bahwa kemampuan guru mengajar dipengaruhi oleh motivasi kerja guru atau motivasi kerja guru berkontribusi terhadap kemampuan guru mengajar agama Hindu.

Berdasarkan teori yang ada yaitu teori dua factor yang menerangkan bahwa factor motivasi terdiri dari: (1) prestasi, (2) pengakuan, (3) pekerjaan itu sendiri, (4) tanggung jawab dan (5) kenaikan pangkat dan pertumbuhan jabatan. Menurut Stoner (1982) orang-orang yang berhasil dalam pekerjaannya adalah orang yang rata-rata mempunyai motivasi tinggi. Hal senada juga dikemukakan oleh Hadari (1987) motivasi kerja (work motivation) adalah sikap atau perasaan-perasaan yang timbul pada diri seseorang terhadap pekerjaannya dalam rangka memenuhi kebutuhan yang dapat menyebabkan naik dan turunnya semangat dan kegairahan kerja.

Hubungan antara Semangat Kerja Guru dengan Kemampuan Guru Mengajar Agam Hindu

Temuan dalam penelitian ini menunjukkan bahwa terdapat hubungan yang positif dan signifikan antara semangat kerja guru dengan kemampuan guru mengajar agama Hindu berdasarkan persamaan $\hat{Y}=10,046+0,0529 \times 3$, dengan koefisien determinannya 0,074 berarti kontribusi sebesar 7,4\%. Semangat kerja guru tergolong dalam kategori tinggi, dengan rata-rata 52,1 dari skor maksimal ideal 60 . Hal ini menunjukkan bahwa kemampuan guru mengajar dipengaruhi oleh semangat kerja guru atau semangat kerja guru berkontribusi terhadap kemampuan guru mengajar agama Hindu.

Dari hasil penelitian Strickland (dalam Gorton, 1976) bahwa meningkatnya semangat kerja disebabkan oleh factor yaitu; (1) rekan kerja yang kooperatif dan suka membantu dalam membagikan gagasan dan materi, (2) kepala sekolah yang kooperatif dan senang menolong, (3) orang tua murid yang kooperatif dan apresiatif, (4) perlengkapan dan fasilitas yang memadai, (5) kebebasan mengajar, (6) murid yang sopan, (7) bangunan sekolah yang memadai, (8) minat murid dalam pekerjaan sekolah, (9) supervisor yang suka menolong dan (10) sekolah terorganisasi dan kebijakan yang terformulasi dengan baik.

Hal yang senada juga dikemukakan Napier yang dikutip oleh Gorton (1976) ada dua belas factor yang berkaitan dengan tingginya semangat kerja guru yaitu; (1) pengertian dan penghargaan administrator kepada guru sebagai suatu individu, (2) kepercayaan guru terhadap kompetensi professional administrator, (3) dukungan yang diterima guru dalam menanggulangi masalah-masalah disiplin, (4) partisipasi guru dalam perumusan kebijakan yang akan mempengaruhi mereka, (5) perlengkapan dan fasilitas, terutama media pengajaran yang memadai, (6) tugas-tugas mengajar yang setaraf dengan tingkat pendidikan, (7) distribusi tugas-tugas ektra kurikuler yang adil dan pantas, (8) latihan professional yang diselenggarakan melalui suatu program latihan dalam jabatan, (9) jaminan kerja, (10) distribusi bahan pengajar yang adil dan merata, (11) kebijakan yang layak tentang cuti, dan (12) gaji yang sebanding dengan profesi yang membutuhkan latar belakang yang setaraf.

Hubungan secara bersama-sama antara Disiplin Kerja Guru, Motivasi Kerja Guru, Semangat Kerja Guru dengan Kemampuan Guru mengajar Agama Hindu

Hasil penelitian ini menunjukkan bahwa terdapat hubungan yang positif dan signifikan secara bersama-sama antara disiplin kerja guru, motivasi kerja guru, semangat kerja guru dengan kemampuan guru mengajar agama Hindu melalui persamaan regresiY $=0,762+$ $0,0472 \times 1+0,0348 \times 2+0,0553 \times 3$, dengan koefisien determinannya 0,369 berarti kontribusi sebesar $36,9 \%$. Hal ini artinya variasi kemampuan guru mengajar, dapat dijelaskan oleh disiplin kerja guru, motivasi kerja guru, dan semangat kerja guru secara bersama-sama.

Berdasarkan hasil analisis korelasi parsial jenjang pertama dan jenjang kedua ditemukan, bahwa: 1) Terdapat hubungan yang positif dan signifikan antara disiplin kerja guru (X1) dengan kemampuan guru mengajar $(Y)$ dengan mengendalikan motivasi kerja guru (X2), 2) Terdapat hubungan yang positif dan signifikan antara disiplin kerja guru (X1) dengan kemampuan guru mengajar ( $\mathrm{Y}$ ) dengan mengendalikan semangat kerja guru (X3), 3) Terdapat 
hubungan positif dan signifikan antara motivasi kerja guru (X2) dengan kemampuan mengajar guru (Y) dengan mengendalikan didiplin kerja guru (X1), 4) Terdapat hubungan positif tetapi tidak signifikan antara motivasi kerja guru $(\mathrm{X} 2)$ dengan kemampuan guru mengajar $(\mathrm{Y})$ dengan mengendalikan semangat kerja guru (X3), 5) Terdapat hubungan positif dan signifikan antara semangat kerja guru (X3) dengan kemampuan guru mengajar $(\mathrm{Y})$ dengan mengendalikan disiplin kerja guru (X1), 6) Terdapat hubungan positif dan signifikan antara semangat kerja guru (X3) dengan kemampuan guru mengajar $(\mathrm{Y})$ dengan mengendalikan motivasi kerja guru (X2), 7) Terdapat hubungan yang positif dan signifikan antara disiplin kerja guru (X1) dengan kemampuan guru mengajar agama Hindu $(\mathrm{Y})$ dengan mengendalikan motivasi kerja guru $\mathrm{X} 2$ ) dan semangat kerja guru (X3), 8) Terdapat hubungan yang positif dan signifikan antara motivasi kerja guru (X2) dengan kemampuan guru mengajar agama Hindu ( $\mathrm{Y}$ ) dengan mengendalikan disiplin kerja guru (X1) dan semangat kerja guru (X3), 9) Terdapat hubungan yang positif dan signifikan antara semangat kerja guru (X3) dengan kemampuan guru mengajar agama Hindu (Y) dengan mengendalikan disiplin kerja guru (X1) dan motivasi kerja guru (X2)

Peringkat pengaruh hubungan antara ketiga variabel bebas, yaitu disiplin kerja guru (X1), motivasi kerja guru (X2), semangat kerja guru (X3) dengan variabel terikat, yaitu kemampuan guru mengajar agama Hindu $(\mathrm{Y})$ dapat dilihat dari peringkat koefisien korelasi parsial, yaitu r1-y2.3, r2-y1.3 dan r3-y1.2 yang disajikan pada Tabel 2.

Tabel 2. Peringkat Pengaruh Variabel Bebas jika Dua variabel dikontrol sekaligus

\begin{tabular}{ccc}
\hline Hubungan parsial antara & Koefisien korelasi parsial & Peringkat Pengaruh \\
Y dengan X1 & $r 1-y 2.3=0,450$ & Pertama \\
Y dengan X2 & $r 2-y 1.3=0,362$ & Kedua \\
Y dengan X3 & $r 3-y 1.2=0,330$ & Ketiga \\
\hline
\end{tabular}

Dari Tabel 2 di atas dapat diketahui bahwa koefisien korelasi parsial tertinggi adalah disiplin kerja guru (X1) dengan r1-y2.3 =0,450; artinya (1) hubungan antara kemampuan mengajar guru dan disiplin kerja guru menjadi peringkat pertama jika motivasi kerja guru dan semangat kerja guru dikontrol sekaligus, koefisien korelasi parsial yang kedua adalah variabel motivasi kerja guru (X2) dengan r2-y1.3 =0,362; artinya (2) hubungan antara kemampuan mengajar guru dan motivasi kerja guru menjadi peringkat kedua jika disiplin kerja guru dan semangat kerja guru dikontrol sekaligus, koefisien korelasi parsial peringkat ketiga atau terendah adalah variabel semangat kerja guru (X3) dengan r3-y1.2 =0,330; artinya (3) kemampuan mengajar guru dan semangat kerja guru menjadi peringkat ketiga jika disiplin kerja guru dan motivasi kerja guru dikontrol sekaligus.

\section{Kesimpulan}

Berdasarkan hasil penelitian sebagaimana diuraikan pada pembahasan, kesimpulan mengenai hubungan antara disiplin kerja Guru (X1), motivasi kerja guru (X2) semangat kerja guru (X3) dengan kemampuan guru mengajar agama Hindu $(Y)$ masing-masing adalah sebagai berikut:

1. Penelitian ini menemukan bahwa hubungan antara disiplin kerja guru (X1) dengan kemampuan guru mengajar agama Hindu ( $\mathrm{Y}$ yang dinyatakan dalam bentuk persamaan regresi $\hat{Y}=6,523+0,0467 \times 1$ adalah signifikan. Ini artinya setiap peningkatan satu satuan skor variabel disiplin kerja guru akan dapat meningkatkan kemampuan guru mengajar agama Hindu sebesar 0,0467 pada konstanta 6,523. Demikian halnya koefisien yang menyatakan pengaruh hubungan antara disiplin kerja guru (X1) dengan kemampuan guru mengajar agama Hindu ( $\mathrm{Y}$ ) yaitu ry1 = 0,404 adalah signifikan. Ini artinya disiplin kerja guru memberikan kontribusi terhadap kemampuan guru mengajar agama Hindu. Besarnya variasi kemampuan guru mengajar agama Hindu yang dapat dijelaskan oleh disiplin kerja guru adalah sebesar $16,4 \%$.

2. Penelitian ini menemukan bahwa hubungan antara motivasi kerja guru (X2) dengan kemampuan guru mengajar agama Hindu $(\mathrm{Y})$ yang dinyatakan dalam bentuk persamaan regresi $\hat{Y}=8,721+0,0445 \times 2$ adalah signifikan. Ini artinya setiap peningkatan satu satuan skor variabel motivasi kerja guru akan dapat meningkatkan kemampuan guru mengajar sebesar 0,0445. Pengaruh antara motivasi kerja guru dengan kemampuan guru mengajar agama Hindu dalam bentuk koefisien ry2 $=0,402$ adalah signifikan. Hal ini berarti bahwa motivasi kerja guru memberikan kontribusi terhadap kemampuan guru mengajar agama 
Hindu. Besarnya variasi kemampuan guru mengajar yang dijelaskan oleh motivasi kerja guru adalah sebesar $16,2 \%$.

3. Penelitian menemukan bahwa hubungan antara semangat kerja guru (X3) dengan kemampuan guru mengajar agama Hindu $(\mathrm{Y})$ yang dinyatakan dalam bentuk persamaan regresi $\hat{Y}=10,046+0,0529 \times 3$ adalah signifikan. Hal ini berarti bahwa setiap peningkatan satu satuan skor variabel semangat kerja guru akan dapat meningkatkan kemampuan guru mengajar agama Hindu sebesar 0,0529 pada konstanta 10,046. Demikian juga pengaruh hubungan antara semangat kerja guru dengan kemampuan guru mengajar agama Hindu dalam bentuk koefisien korelasi ry3 $=0,272$ adalah signifikan. Hal ini berarti bahwa semangat kerja guru, memberikan kontribusi terhadap kemampuan guru mengajar. Besarnya variasi kemampuan guru mengajar agama Hindu dapat dijelaskan oleh semangat kerja guru adalah sebesar $7,4 \%$.

4. Penelitian ini menemukan bahwa hubungan antara disiplin kerja guru, motivasi kerja guru dan semangat kerja guru secara bersama-sama dengan kemampuan guru mengajar agama Hindu yang dinyatakan dalam bentuk persamaan regresi $\hat{Y}=0,762+0,0472 \times 1+0,0348 \times 2$ $+0,0553$ X3 dan koefisien korelasi ganda $R$ y. $123=0,607$ adalah signifikan. Hal ini artinya disiplin kerja guru, motivasi kerja guru, dan semangat kerja guru, secara bersama-sama memberikan kontribusi terhadap kemampuan guru mengajar agama Hindu. Sedangkan besarnya variasi kemampuan guru mengajar agama Hindu yang dapat dijelaskan secara bersama-sama oleh disiplin kerja guru, motivasi kerja guru, dan semangat kerja guru adalah sebesar $36,9 \%$.

5. Penelitian ini juga menemukan bahwa berdasarkan koefisien korelasi parsial ternyata (1) hubungan antara didiplin kerja guru dengan kemampuan guru mengajar menempati peringkat pertama jika motivasi kerja guru dan semangat kerja guru dikontrol, (2) hubungan antara motivasi kerja guru dengan kemampuan guru mengajar menempati peringkat kedua jika disiplin kerja guru dan semangat kerja guru dikontrol, dan (3) hubungan antara semangat kerja guru dengan kemampuan guru mengajar menempati peringkat ketiga jika disiplin kerja guru dan motivasi kerja guru dikontrol.

\section{Daftar Pustaka}

Amidjaya, D.T. (1982). Pembaharuan Sistem Pendidikan, Tenaga kependidikan dan Pedoman Pelaksanaannya, Jakarta Buku II, Depdikbub RI.

Arikunto, 1998. Prosedur Penelitian Suatu Pendekatan Praktek (Edisi Revisi ke tiga). Yogyakarta, Rineka Cipta.

Dantes, N., 1996. Orientasi Tentang Profesi Guru dan Pengembangannya. Singaraja : Departemen Pendidikan dan Kebudayaan.

Darmodiharjo, D., 1991. Profesionalisme Pendidikan dan Pengajaran di Sekolah Suatu Rekayasa Pedagogis, IKIP Malang.

Joni, T.R., 1983. Cara Belajar Siswa Aktif, Wawasan Kependidikan, dan Pembaharuan Pendidikan Guru. Pidato Jabatan Guru Besar. Departemen Pendidikan dan Kebudayaan IKIP Malang.

Maslow. Abraham, H., 1970. Motivation and Personality, New York, Evanston, and London.

Maslow, Abraham, H., 1994. Motivasi dan Kepribadian 2, Teori Motivasi dengan

atan Hierarki Kebutuhan Manusia. Jakarta, Penerbit PT. Pustaka Binamaan Press

Naskawati, Anggraini, 2001. Hubungan Status Kepegawaian Guru, Keammpuan Mengajar dan Disiplin Kerja Guru dengan Prestasi Belajar Siswa Sekolah Lanjutan Tingkat Pertama Negeri Di Kota Mataram Nusa Tenggara Barat. Tesis. Tidak diterbitkan. PPS. Universitas Negeri Malang.

Ngurah Made, Dkk., 1999. Buku Pendidikan Agama Hindu, Paramita, Surabaya. 
Paramartha, 2003. Study Tentang Beberapa Faktor Yang Mempengaruhi Kemampuan Guru Mengajar Sejarah Pada Sekolah Lanjutan Tingkat Atas di Kota Denpasar, Tesis, Tidak Diterbitkan. IKIP Singaraja.

Santika, I Made, Dkk., 2003. Kurikulum Pendidikan Agama Hindu Berbasis Kompetensi Sekolah Dasar. Jakarta : Departemen Pendidikan Nasional. Direktorat Pendidikan Dasar dan Menengah. Bagian Proyek Peningkatan Wawasan Pendidikan Guru Agama.

Wijaya, 1991. Kemampuan Dasar Guru dalam Proses Belajar Mengajar, Bandung : Penerbit PT. Remaja Rosda Karya. 